\title{
GENDER CONCEPTS IN MODERN UKRAINIAN MEDIA
}

\section{CHORNODON Myroslava,}

Ph.D. (Social Communications), Senior Lecturer,

Vasyl' Stus Donetsk National University, 21 600-richchia str., Vinnytsia, 21021, Ukraine, e-mail: muroslavachornodon@ukr.net.

The urgency of the topic of the scientific article is determined by the processes of finding new concepts and applying new approaches to the study of the gender concept of the modern periodicals for women and men in Ukraine. The study of the gender concept is relevant because it reveals new trends and features of modern gender images. The purpose of the article is due to the processes of finding new concepts and the application of new approaches to the study of gender concepts in modern Ukrainian media. The study of the topic is relevant because it allows to identify new trends and features of modern gender images. The macroconcept «woman» can be conventionally divided into the main, that is, the most frequently used microconcepts in the magazines studied, such as: loved one, mistress, mother, girlfriend, mother-in-law, rival. As it turned out, in the studied editions, the macro concept of "man" is reflected in the most frequently used microconcepts: beloved, father, stranger, boss, son, friend. At the core of the gender conceptual sphere there is basic gender macro concepts «woman》 and «man» that is used in the investigated periodical in different proportions, depending on the role of women and men in society. Especially because of the sensitivity, thoughtfulness, responsible selection of gender characteristics, which is presented in a gender-labeled periodical, modern and future is formed gender images.

Key words: gender, concept, conceptual sphere, content analysis, paradigm.

\section{ГЕНДЕРНІ КОНЦЕПТИ В СУЧАСНИХ УКРАЇНСЬКИХ МЕДІА}

Мета наукової публікацї̈ полягає в досліджненні гендерних концептів в сучасних украӥнських медіа. Визначено особливості вживання гендерних концептів у сучасній періодиці для жінок та чоловіків. Виявлено найчастіше вживані похідні иих макроконцептів, тобто їх лікроконцепти та детально їх проаналізовано. З’ясовано, що видання для жінок та чоловіків насичені різноланітнили гендернили концептали, які вживаються у різних контекстах. Актуальність тели наукової статті зуловлена процесали пошуку нових концепиій та застосуваннял нових підходів до вивчення гендерних концептів в сучасних українських медіа. Вивчення тели є актуальним, оскільки дозволяє виявити нові тенденцї та ознаки сучасних гендерних образів. Основні результати дослідження. Макроконцепт «жінка» умовно можна поділити на основні, тобто найчастіше вживанні у досліджуваних журналах мікроконцепти, а сале такі: кохана, коханка, мати, подруга, свекруха / теща, супернищя. Як виявлено, у досліжжуваних виданнях макрокониепт «чоловік» відображається у таких найчастіше вживаних мікроконцептах: коханий, батько, незнайолець, начальник, син, друг. Головні висновки дослідження. В основі гендерної концептосфери функиіонують базові гендерні макроконцепти «жінка» й «чоловік», які вживаються у досліджуваній періодиці в різних співвідношеннях в залежності від того, які ролі виконуються жінкою чи чоловікол у суспільстві. I сале від виваженості, вдулливості, відповідального підбору гендерних характеристик, що подаються у гендерно маркованій періодиці форлуються сучасні та майбутні гендерні образи.

Ключові слова: гендер, концепт, концептосфера, контент-аналіз, парадигла.

$I^{\prime}$

ntroduction. The urgency (Topicality of the research) of the topic of the scientific article is determined by the processes of finding new concepts and applying new approaches to the study of the gender concept of the modern periodicals for women and men in Ukraine. The study of the gender concept is relevant because it reveals new trends and features of modern gender images. Taking into account the special features of gender-labeled periodicals in general and the practical absence of comprehensive 
scientific studies of the gender concept in particular, there is a need to supplement Ukrainian science with this topic.

A small number of works devoted to the study of the concept. The most prominent is the doctoral dissertation by L. Vasylyk «Suchasna hlobal'na publitsystyka literaturno-khudozhnikh vydan' v konteksti istoriyi ukrayins'koyi zhurnalistyky: kontseptsiya natsional'noyi identychnosti" ("Modern global journalism of literary and artistic editions in the context of the history of Ukrainian journalism: the concept of national identity"). Candidate's theses on social communications related to the study of concepts and conceptual peculiarities: M. Masimova's «The Concept of Man and the World in Journalism and the Artist of Art Umberto Eco», N. Zhelihovskaya «Conceptual and Thematic Features of Ukrainian Journalism in the Other Half of the 80s of the 20th Century». As for the study of gender peculiarities, the definition of gender in the Ukrainian language: N. Ostapenko, N. Sidorenko, M. Skoryk, V. Slinchuk, T. Starchenko, L. Stavytska, O. Sushkova, O. Poda, Ya. Puzirenko, L. Taran, O. Taranenko. Gender problems were raised in scientific articles by O. Dudoladova, O. Goroshko, L. Kompantseva, O. Semikolienova, L. Sinelnikova, K. Pischikova.

This scientific article is a step in highlighting the gender conceptual sphere of modern periodicals for women and men in Ukraine as an integral part of Ukrainian society.

The purpose of the article of the research is to study the gender concept in the contemporary periodicals (for example, such magazines as women: «Schaslyva», regional - «Woman», «Women's magazine», «Natalie», «Cosmopolitan», magazines for men: regional ones - «Major», «His own», all-Ukrainian - «Men's Health», «EGO», «Esquire») in the psycholinguistic paradigm of research using linguistic, psychological, psycholinguistic and socio-psychological methods of science.

To achieve this goal, the following tasks were set: to find out the level of scientific study of the gender concept in Ukraine; to reveal the issue of gender roles and stereotypes in the studied editions; to define the features of the use of gender concepts in the pages of modern gender-stamped periodicals; to highlight the diversity of gender images in modern periodicals for women and men based on gender concepts.

The object of research is modern gender-labeled Ukrainian media.

The subject of research is gender concepts in modern Ukrainian media.

Methods of research. Gender psychology, which is served by methods of various sciences, primarily sociological, pedagogical, linguistic, psychological, socio-psychological. Let us pay attention to linguistic and psycholinguistic methods in gender studies. Linguistic methods complement intelligence research tasks, associated with speech, word and text. Psycholinguistic methods used in gender psychology (semantic differential, semantic integral, semantic analysis of words and texts), aimed at studying speech messages, specific mechanisms of origin and perception, functions of speech activity in society, studying the relationship between speech messages and gender properties participants in the communication, to analyze the linguistic development in connection with the general development of the individual.

Nowhere in gender practice there is the whole arsenal of psychological methods that allow you to explore psychological peculiarities of a person like observation, experiments, questionnaires, interviews, testing, modeling, etc.

The methods of psychological self-diagnostics include: the gender aspect of the own socio-psychological portrait, a gender biography as a variant of the biographical method, aimed at the reconstruction of individual social experience. In the process of writing a gender autobiography, a person can understand the characteristics of his gender identity, as well as ways and means of their formation.

Socio-psychological methods of studying gender include the study of socially constructed women's and men's roles, relationships and identities, sexual characteristics, psychological characteristics, etc. The use of gender indicators and gender 
approaches as a means of socio-psychological and sociological analysis broadens the subject boundaries of these disciplines and makes them the subject of study within these disciplines.

And also, in the article a combination of concrete-historical, structural-typological, system-functional methods is implemented. Descriptive and comparative methods, method of typology, modeling is used. Also used is a method of content analysis for the study of gender content of modern gender-stamped journals. It was he who allowed quantitatively to identify and explore the features of the gender concept in the pages of periodicals for women and men.

Results and discussion. The conceptual perception and interpretation of the gender concept "woman", which is highlighted in the modern gender-labeled press in Ukraine, requires the elaboration of the polyfunctionality of gender interpretations, the comprehension of the metaphorical perception of this image and its role and purpose in society.

It is interesting to explore the gender conceptual sphere through the prism of the species characteristics of the concepts. All concepts can be conventionally divided into macro and microconcepts, or in other words on concept-maximum and concept-minima. The framework of the gender concept is two concepts that focus on gender relations in society - «man» and «woman», which are denoted as macro concepts or concept-maximum [9, c. 95].

The concept, the concept sphere is gendered, enabling a gendered approach to researching the gender content of contemporary periodicals for women and men. Conceptual analysis of contemporary gender-stamped publications within the gender conceptual sphere allows to identify and correlate the meta-gender and gender concepts that appear in society.

The concept and the conceptual sphere are gendered, enabling a gendered approach to researching the gender content of contemporary periodicals for women and men. Conceptual analysis of contemporary gender-labeled publications within the gender conceptual sphere allows us to identify and correlate the meta-gender and gender concepts that appear in society.

The researcher L. Vasylyk describes the concept-maximum as the full understanding of the meaning of the word that is typical of a native speaker, to which reality is known in its entirety. This concept contains encyclopedia information that extends the concept-maximum due to additional knowledge about the object. Instead, the conceptminimum means incomplete knowledge of the meaning of the word that is typical of a native speaker, to which the reality itself is known, but is supposedly peripheral to its practice of life [2, c. 214].

The macroconcept «woman» can be conventionally divided into the main, that is, the most frequently used microconcepts in the magazines studied, such as: loved one, mistress, mother, girlfriend, mother-in-law, rival.

A loved one - this microconcept, of course, comes into the context of «a person / woman" and reflects the attitude of men to women, boys to girls. The microconcept "loved one» in all cases of life positively describes and characterizes a woman with the best of her sides: A happy woman is a loved woman («Natalie». - 2020. - No. 3). This concept reflects a woman who is bathed in the love and affection of her husband, who is ready to submit everything for her: Everything is at your feet, my beloved, and I am also a serpent on a short chain («Natalie». - 20020. - No. 2). In use the «loved one» can be replaced with the following synonyms: dear, sweet, one and only; of ten compared to such animals and birds as a cat, a bunny, a swallow, a winch.

A mistress - this microconcept is used in a negative light, in particular in the context of "wife - husband - mistress" relationship. And first of all the mistress is compared with such animals: a snake, a viper, a lizard, a frog. Calling a woman like that characterizes her as an insidious, scumbag, cunning person: A serpant on a short chain ("Cosmo- 
politan». - 2020. - No. 4); A girlfriend is a viper, and a man is a chameleon («Women's Magazine». - 2020. - No. 5).

A friend - this microconcept is covered both in a positive and a negative color. Firstly, a friend is a faithful person, who is always ready to give up his shoulder, to listen and give advice: A girlfriend will not leave her in trouble («Mini». - 2020. - No. 4). Secondly, the concept «friend» is depicted on the pages of the published editions in the context of the "pseudo-friend", who is ready to be friendly for some purpose, that is not always good: Snake in Sheep's Skin («Natalie». - 2020. - No. 2.) Sometimes this pseudo-friend sets up someone's husband as a goal. In this case, the friend becomes a rival.

A rival - this is one of the largest inhabitants in the study of periodicals' macroconcepts. And of course, the concept of «rival» is manifested in the gender ratio "woman - man - woman», where a person acts as the main prize: Who will get a super prize («Mini». - 2020. - No. 4); Two women and one man («Natalie». - 2020. - No. 5).

A mother - this microconcept is one of the most used on the pages of the studied periodicals, more often in magazines for women. The concept «mother» is used in the positive (more) and negative (less) semantic loading. In a positive context, "Mom» is caring, kind, affectionate, the one who understands and forgives all, a close person: My mother is the best friend ( Schaslyva». - 2020. - No. 2). In the negative context, the concept "mother" is used quite rarely, but in several magazines there are materials in which a mother appears as a so-called «cuckoo». That is the biological mother, who leaves her child for other matters or interests: The Cuckoo Dropped and Failed («Woman». - 2020. - No. 2). The negative concept of «mother-cuckoo» shows the topic of abortion: Kill for a Goal ( Natalie». - 2020. - No. 3). Thus, the studied concept «mom» has different meanings. However, the concept of «mother» is much more often depicted by the bright, pure, beautiful image of the mother. The mother in the periodicals for women and men is often compared to the guardian and the protector.

A mother-in-law is the most commonly used microconcept in the periodicals surveyed for women and men. First, consider the microconcept «introspection», this microconcept is not always used in a positive context. The mother-in-law is a husband mother who is often portrayed too curious, full of knowledge and with a constant desire to help his son and his family and thus interfere in the life of a young family, which does not always help, and, on the contrary, hurts its perseverance. She also turns his son into a so-called «mummy's son»: My husband is a mummy’s son («Natalie». - 2020. - No. 4); The mother-in-law ruined our family («Women's Magazine.» - 2020. - No. 2). In the positive context, the mother-in-law is depicted in the image of a friend. This image is definitely positive and helps readers find a common language and even talk with the mother-in-law if there are certain problems: Introspective: an enemy or a friend («Natalie». - 2016. № 1.) The microconcept of «mother-in-law» is often used with a comic semantic loading and therefore is often more positive than negative. This concept is relevant both in publications for women and men: The mother-in-law has all in the sight («Woman». - 2020. - No. 4); Under the heel of mother-in-law («Natalie». - 2020. - No. 2).

Staying on the spiritual characteristics of a woman associated with her inner mental life, stereotyped peculiarities of female nature, one should highlight the conceptual sign of «the women's natural ability to be to be raised, influenced»: a sack, a vine, a soul - a woman who is completely devoid of any beliefs, values, orientations and, in general, any qualities that make up the notion of «personality»; she can completely dissolve not only in male affairs, but also in his character, habits, preferences ...».

Among the positive moral and ethical qualities, the following signs are actualized: conscientious attitude to work; ability to be worthy of self; the ability to bring confidence to you.

The leading model of gender relations in society is reflected by the media mainly in stereotyped images of men and women. The analysis of the gender roles of a woman and 
a man allows a deeper understanding of the concept of a woman, a man, their branches mother, wife, father, etc.

Gender relations are indivisible and always mutually predetermine and subconsciously complement each other, their content is revealed through the principle of unity of opposites, which are in constant social interaction.

The main gender concepts and their derivatives, as well as the correlation between them, are revealed for the study of the gender conceptual sphere. It is revealed that gender concepts coexist in close interaction with each other, that is, the concept of «woman" finds its reproduction in the concept of «man». This is highlighted in such a categorical relation as «a woman - a man», which, for its part, is divided into different categories: «wife - husband», «mother - child» («mother - daughter», "mother - son»), "woman - mother-in-law», "girl - boy», "girlfriend - boyfriend», «boss - subordinate», "subordinate - boss». And these interconnections can be used in investigated editions with different semantic loadings, that is, in different contexts, both positive and negative. So, it means performing various interpersonal functions, and sometimes social roles. That is, gender-labeled periodicals are not limited to covering only the positive image of a woman.

As it turned out, in the studied editions, the macro concept of «man" is reflected in the most frequently used microconcepts: beloved, father, stranger, boss, son, friend.

Let's take a closer look at these concepts:

Beloved - this microconcept has both a positive and a negative connotation and is accordingly used in the gender conceptual relation of «man - woman». The concept of «beloved», of course, is more oftenly used in a positive context. And it is characterized by such qualities as tenderness, courtesy, generosity, care: Beloved is ready for everything («Natalie». - 2020. - No. 4); My beloved gave a star ... («Women’s Magazine». - 2020. - No. 2). But there are cases where the concept of «beloved» is used in a negative context, namely: «beloved / traitor», «beloved / miserly», «beloved / work»: The betrayal has erased our family ( «Natalie». - 2020. - No. 4); Work is number 1, and I ... ( «Schaslyva». - 2020. - No. 4.) The concept of «beloved» in relation to work is used not only in negative reflection, because it takes too much, but also in a positive way in the case when the work brings a lot of profits and pleasure: My favorite workaholic with a thick purse («Women's Magazine» . - 2020. - No. 5); His work is my money ( Cosmopolitan». - 2020. - No. 1).

Father - this microconcept is identified as the most commonly used in the studied periodicals in the ratio of «father and child». This microconcept is reflected in a positive context, in this case, the image of the father is characterized by such features as: care, help, attention, sincerity: Parental attention is priceless for a child («Schaslyva» . - 2020. - No. 1). The concept «father» also has a negative coverage: Father is a traitor («Natalie». - 2020. - No. 1); He (father) left us when I still could not speak («Women’s Magazine». - 2020. - No. 2).

Stranger - this microconcept is used in the most commonly used (in our category study) relation "woman and man" and is mainly positive: Stranger from my dreams («Natalie». - 2020. - No. 3); The stranger presented me with 101 rose («Schaslyva». 2020. - No. 6). This concept is exclusively positive on the pages of the periodicals (more often for women) and is replaced by a synonym such as the magician: I first saw a wizard on my threshold («Women's Magazine». - 2020. - No. 1).

Boss - this microconcept is often replaced by the following synonyms: the boss, the chief, and sometimes the senior colleague: Yes, the boss, I listen carefully ( Cosmopolitan.» - 2020. - No. 1.) This microconcept has both a positive and Negative reflection: In a positive way, the concept of «boss» is used in the context of a generous employer: My salary allows me a lot ...» («Cosmopolitan». - 2020. - No. 2). And the negative - as a strict, powerful one, who controls everything and all: The Tyrant Leader is My Dread ( "Natalie». - 2020. - No. 2.) It should be noted that the microconcept «tyrant» is one of 
the most distinguished, most used in the periodic study for women and men, although it is sometimes used in the context of "woman and man", that is, a man, often a legitimate man, who allows himself a bad, contemptuous, evil attitude to his wife: My lawful husband is a true tyrant ( «Natalie». - 2020. - No. 2); The Despot at Home ( "Women's Magazine». - 2020. - No. 5). Accordingly, the microconcept «tyrant» is reflected in such a synonym as a despot. The microconcept «legitimate man», mentioned above in the negative context, does not distinguish a separate group of most often used microconcepts, because referring it to a group of microconceptual «beloved», which was previously considered. Returning to the microconcept, «the boss», it is worth noting that sometimes this image is covered in the role of a lover: Boss and lover - two in one ( Cosmopolitan». - 2020. - No. 4) - material under this heading reveals the image of the boss in exactly the lover's context.

A son - this microconcept is most often also used in relation to "woman and man", but the concept "woman», in particular in the micro-concept «mother», that is, in the attitude of son to mother: Mother - love for life («Natalie». - 2020. - No. 2). As well as this microconcept is used in the gender ratio "mother - son - lover», as a rule, in this case is more often negative than a positive color, because the concept "man" is used in the sense of «momsyn son»: On my pity, he turned out to be a real mummy son («Cosmopolitan». -2020 . - No. 8).

A friend - this microconcept is one of the most mentioned in the investigated periodicals. And gender is used in the «male / female», «male / male»: My friend is my antibiotic («Women's Magazine». - 2020. - No. 8.) In relation to «man / woman,» man acts in a metaphorical role of a strong shoulder, a girlfriend in the masculine body: I have a girlfriend of $100 \mathrm{~kg}$ and can bring me home if I need to ... («Mini». - 2020. - No. 6). And in relation to «man / man" the microconcept «friend" is, above all, a strong spirit in a strong man's body, ready to always come to the rescue or to be the company in the gym as well as in the bar: A friend in trouble will not leave («EGO». - 2020. - No. 5); True Friend is Iron ( Mens Health». - 2020. - No. 6); Beer and the main thing ("Your». 2020. - No. 2).

American psychologist Sandra Bam created a psychological method for measuring masculinity and femininity, the "Bem Sex-Role Inventory", according to which four types of people can be diagnosed regardless of their physiological gender: masculine (with expressive male qualities); feminine (with pronounced feminine qualities); androgynous; uncertain (without the expressed qualities of masculinity and femininity).

One of its most significant components is gender-role (or gender) socialization. Gender-role socialization is the assimilation of gender roles, social expectations of these roles, as well as gender development of personality, that is, the formation of psychological characteristics that correspond to gender roles. These roles are closely related to the awareness of a representative of a particular gender and with the standards of behavior characteristic of the representatives of this gender.

Gender socialization has a number of peculiarities and specific difficulties for men and women. From birth, the child enters the social environment, which sets a number of stereotypes of gender-role behavior. By the way, the child hears from his parents, tutors: «It's not good, it's not something a girl (boy) would do»; «Do not cry, boys do not cry!»; «Do not be afraid, the girls do not behave like this!» With the first manifestations of the awareness of a representative of a certain sex, the child connects it with a number of features: with clothing, rules of conduct, manifestations of feelings or prohibitions on them [7, c. 38].

It is in the magazines for men that the theory of the gender male role is maintained. And in women's, on the contrary, women want to see men more gentle, emotional, spontaneous, capable of unpredictable actions, which does not correspond to the theory of the gender male role, developed by D. Thompson and J. Plec. Common to both types of publi- 
cations is the fact that gender concepts are not separate the concept of "person» is mentioned in the context of "man - woman", their relationships in various aspects of life.

Conclusions and perspectives of further study. Typical features of femininity and masculinity, first of all, socially fixed norms, stereotypes, and not the result of objective natural differences between genders. In some cases, these features really reflect the average differences between men and women. But often, they are the result of education, when psychological differences are formed under the pressure of stereotypes imposed on a person by society. And it happens that the traditional features of femininity and masculinity contradict the true nature of people. In particular, until recently it was considered that women have a more emotional attitude, and men are more inclined to logical thinking. Modern studies of neurophysiology argue that in women on the average more advanced is the left (logical) brain hemisphere, and in men - rights (emotional). In particular, most researchers in the field of differential psychology agree that girls have more advanced speech abilities (related to the left hemisphere) than boys. However, history shows that most writers at all times and ages were men. Women and men are really different, but these differences are not always identical with public stereotypes. Real gender differences are a combination of natural differences and upbringing.

The level of scientific study of the gender conceptual sphere is clarified. It is highlighted that the concept is a multidimensional complex represented in the language, which has a certain ethnocultural specificity. The concept has an unstable structure, which is reflected in the conceptual model developed by us, in which we distinguish the root and applications of the concept, the movement of signs in the actual content directions from and to the root is possible. The unstable (mobile) structure of the concept is also characteristic of its root: during the historical development of the roots may change, but the meaningful value is not lost, but replaced by synonyms or verbal neoplasms, relevant to the present.

The macroconcept "woman» can be conventionally divided into the main, that is, the most commonly used microconcepts in the magazines being studied, namely, the following: loved one (26\%), mistress (23\%), friend (14\%), rival (12\%), mother (11\%), mother-in-law $(9 \%)$, others $(6 \%)$.

In the studied editions, the macroconcept «man» is reflected in the most frequently used microconcepts: beloved (30\%), father (21\%), stranger $(17 \%)$, boss $(12 \%)$, son $(10 \%)$, friend ( $7 \%)$ others $(4 \%)$.

Thus, the coverage of the gender concept of «man» on the pages of publications for men and women is different. For example, in female editions, a man is most often described in relationships with women, only then - as a professional in his case, almost no attention is paid to the appearance of a man. That is, the inner essence of a man is important for a woman (based on materials of magazines). As for the concept of «man» in the pages of publications for men, then the very appearance is devoted a significant part of publications. It is also important for men to have proper nutrition, career development, success, status in society. And the coverage of the gender concept «woman» in gender-stamped periodicals confirms the opinion that most modern women are trying to show themselves both in work and in relationships with men, performing various social roles. They combine professional and family spheres of life. Important is the spiritual development of a woman as a purposeful person who tries to maintain a form and monitor her appearance. The image of a fully developed woman is a major issue in the pages of contemporary periodicals for women, proving an analysis of their content. It is worth noting that in the magazines for men, the concept of «woman" is no less important, and it is implemented in the context of «man - woman», in particular in terms of work, hobbies, rest, relationships. Concepts of "woman» and «man" coexist, unity of «man - woman». Relationship with the opposite sex is an actual topic for both women and men's periodicals. 
The prospects for further research are at the core of the gender conceptual sphere there are basic gender macro concepts "woman» and "man» that are used in the investigated periodical in different proportions, depending on the role of women and men in society. Especially because of the sensitivity, thoughtfulness, responsible selection of gender characteristics, which are presented in a gender-labeled periodical, modern and future gender images are formed, ideas about ideal women and men is popularized, as well as their needs, opportunities, duties in the family, at work, and in general in all spheres of life; the spiritual and psychological component of society is formed.

1. Batsevych, F. S. (2007) Slovnik terminiv mizhkulturnoï komunikatsiï). Kyiv : Dovira. 205 s. [in Ukrainian].

2. Vasylyk, L. C. (2010) Svitoglyadna publitsistika suchasnikh literaturno-khudozhnikh vidan: kontseptosfera natsionalnoï identichnosti : monogr. - Chernivtsi : Bukva. 431 s. [in Ukrainian].

3. Gallagher, M. I. (2001) Gender setting : new agendas for media monitoring and advocacy. London : WACC. 217 p. [in Ukrainian].

4. Greenaway, K. (1972). Mother Goose. L. : Dover Publications. [in Ukrainian].

5. Sliepina, N. (2012). Kontsept, poniattia, slovo, znachennia: teoretychni problemy rozmezhuvannia [Concept, notion, word, meaning: theoretical problems of differentiation]. Psycholinhvistyka - Psycholinhuistics, 11, 204-212 [in Ukrainian].

6. Slovnyk ukrainskoi movy [Dictionary of the Ukrainian Language] (1970). (Vols. 1-11). Kyiv : Naukova dumka [in Ukrainian].

7. Khamitov N .I. (2000; September 6) Filosofiya stati. Filosofska dumka. 315; 35-46. [in Ukrainian].

8. Tlumachnyi slovnyk ukrainskoi movy [Explanatory Dictionary of the Ukrainian Language]. (n.d.). eslovnyk.com. Retrieved from http://eslovnyk.com [in Ukrainian].

9. Chukhim, N. D. (2001; April 4) Problemi i perspektivi feministichnoï teoriï. Gender i kultura. $296 ; 94-101$.

10. Yaremenko, V. \& Slipushko, O. (2008) Novyi tlumachnyi slovnyk [New Explanatory Dictionary]. (Vols. 1-2). Kyiv: Akonit [in Ukrainian].

\section{УДК 007:304:070}

\section{ГЕНДЕРНІ КОНЦЕПТИ В СУЧАСНИХ УКРАЇНСЬКИХ МЕДІА}

Чорнодон Мирослава, канд. наук із соц. комунік., доцент,

Донецький національний університет імені Василя Стуса, вул. 600-річчя, 21, Вінниця, 21021, Україна, е-mail: muroslavachornodon@ukr.net.

ORCID - https://orcid.org/0000-0002-9227-0993

Вступ. Актуальність теми наукової статті зумовлена процесами пошуку нових концепцій та застосуванням нових підходів до вивчення гендерних концептів сучасної періодики для жінок і чоловіків в Україні. Вивчення гендерних концептів є актуальним, оскільки дозволяє виявити нові тенденції та ознаки сучасних гендерних образів.

Мета роботи полягає у з'ясуванні гендерних концептів у площині дослідження сучасної періодики для жінок і чоловіків.

Методи дослідження. Гендерна психологія послуговується методами різних наук, насамперед соціологічних, педагогічних, лінгвістичних, психологічних, соціально-психологічних.

Результати. Концепт, концептосфера включають гендерні ознаки, що уможливлює гендерний підхід для дослідження гендерного контенту сучасної періодики для жінок та чоловіків. Концептуальний аналіз сучасних видань у межах гендерної концептосфери дозволяє виявити й співвіднести метагендерні та гендерні концепти, що фігурують у суспільстві. 
Виявлено основні гендерні концепти та їх похідні, а також співвідношення між ними. 3'ясовано, що гендерні концепти співіснують в тісні взаємодії між собою, тобто концепт «жінка» знаходить своє відображення у концепті «чоловік» це висвітлено у такому категоріальному співвідношенні як: «жінка - чоловік».

Висновки. В основі гендерної концептосфери функціонують базові гендерні макроконцепти «жінка» й «чоловік», які вживаються у досліджуваній періодиці в різних співвідношеннях в залежності від того, які ролі виконуються жінкою чи чоловіком у суспільстві. I саме від виваженості, вдумливості, відповідального підбору гендерних характеристик, що подаються у гендерно маркованій періодиці формуються сучасні та майбутні гендерні образи, популяризуються уявлення про ідеальних жінок і чоловіків, їхні потреби, можливості, обов'язки у сім'ї, на роботі, й загалом у всіх сферах життєдіяльності а отже формується духовна і психологічна складова суспільства.

Ключові слова: гендер, концепт, концептосфера, контент-аналіз, парадигла.

Стаття надійшла до редакції 11.02.2021. 